\section{ONOMÁVADIN}

Revista semestral de lingüística, filología y traducción
PONTIFICIA UNIVERSIDAD

\title{
Current Perspectives in Teaching English for Specific Purposes
}

\author{
Jesus Garcia Laborda \\ Universidad de Alcalá \\ España
}

\section{Mary Frances Litzler}

Universidad de Alcalá

España

\section{(C) $\bigodot_{\mathrm{BY}} \bigodot_{\mathrm{ND}}$}

Jesus Garcia Laborda: Departamento de Filología Moderna, Universidad de Alcalá, España | Correo electrónico: jesus.garcialaborda@uah.es

Mary Frances Litzler: Instituto Franklin, Universidad de Alcalá, España. | Correo electrónico: mf.litz@uah.es 


\section{Abstract}

Interest in Languages for Specific Purposes (LSP) courses has grown in recent years (Harding, 2007). For this reason a paper on the current situation in the field is of relevance. The present article provides a discussion of English for Specific Purposes and it does so by reviewing the history and background of this area of teaching, proposing a definition, and describing issues affecting it today, such as course design and needs analysis, context, student and teacher characteristics, materials, and expected directions for the future.

Keywords: Language teaching; EFL; course design; materials; Learner characteristics; ESP; Business English. 


\section{History and Background}

The purpose of this article is to provide an up-to-date view of the field of English for Specific Purposes (ESP). It will discuss a brief history, definitions, and issues affecting the field today. These aspects include course design and needs analysis, student and teacher characteristics, and materials. Hutchinson \& Waters (1987) have suggested that the teaching of English for Specific Purposes (ESP) was not born as a coherent type of teaching but as an evolution that responded to the needs of learners of language for science, technology and business especially after the Second World War (1937-1946). Instead of learning English for prestige or pleasure, they learned it for work reasons. This development came about specifically due to three main factors: 1) the demands of work in a changing global world; 2) continuous development in linguistics; 3) and a focus on the learner (for a more extensive contextualization see also Howatt \& Widdowson, 2004). However, Howatt \& Widdowson later suggest that the first courses in languages for specific purposes can be dated as far back as the beginning of the last century and they provide examples of French commercial correspondence courses around the first decade of the 2oth century.

In the 1920S West (also cited by Howatt \& Widdowson, 2004) became the first known textbook writer to account for the scientific and business needs of his target audiences. His followers, including Salzedo, also wrote a number of basic textbooks for business, astronomy and other areas. However, the 1930 s and 1940 s saw a shift in language learning from adults to children and this meant that it would not be until very late in the 1940s that ESP would take on an important role in language pedagogy again, only becoming a prevailing option in language learning from the 1960 s.

A few years ago Harding (2007: 3) indicated that in recent years there has been a renewed demand for English for Specific Purposes cours- es. His reasons to explain this increased interest include better student levels of proficiency at the end of high school (Denman et al., 2013), the perception of English as key to finding a job as it is the language of international communication, and more use of Content and Language Integrated Learning (CLIL) (Ioannou Georgiou, 2012) at the high school level (Nordmeyer \& Barduhn, 2010). In fact, CLIL has led to a shift from language based ESP to a content subject aimed language learning with special implications in attitudes and student creativity (Airey, 2012; Cross, 2012; Unterberger, 2012).

\section{Towards a definition of English for Specific Purposes}

English for Specific Purposes (ESP) classes in a foreign language context can be differentiated from English for General Purposes in that the former are more directed towards the immediate professional or academic demands and applicable situations. It is not a straightforward task to give one overall definition for this area of teaching-learning to cover all of the courses offered today given the "growing body of research and theory, and ever-diversifying and expanding range of purposes" (Belcher, 2006: 134). This perception is complicated by the fact that there are differences between ESP in an EFL context compared to an ESL context. Nevertheless, an attempt at providing an up-to-date definition will be made here.

Many descriptions provided in the literature relate to the broad distinction of ESP versus EGP. Richards \& Schmidt (2010) define Languages for Specific Purposes as languages "used for particular and restricted types of communication (e.g. for medical reports, scientific writing, air-traffic control) and which contain lexical, grammatical, and other linguistic features which are different from ordinary language” (2010: 295). Richards \& Schmidt also add that "the content and aims of the [ESP] course are fixed by the specific needs of a particular group of learners" (2010: 181). In 
this sense, ESP needs to be defined in relation to "a large number of separate activities defined according to a subject or a profession or job" (MCDonough, 1999: 105) that lead learners to study English in that very same context, profession or job. This problem has led specialists of ESP to address English as much smaller sub-divisions, such as English for the Maritime, English for Aviation, English for Business, apart from the traditional subdivisions of English for Academic Purposes or English for Occupational Purposes.

Many authors echo this notion of more specific language and communication characteristics and distinct groups of learners. According to Mohan (1986: 15), ESP aims to prepare students "for chosen communicative environments" in which English "is used for a limited range of communicative events" (in Basturkmen \& Elder, 2004: 672). In this sense, "the content and aims... are fixed by the specific needs of a particular group of learners" (Richards \& Schmidt, 2010)
For example, in a business context the language and learning tasks tend to be used in predictable situations (Evans, 2012; Greer, 2012; Trinder, 2013; Trinder \& Herles, 2013) such as professional presentations, meetings, customer / client relations and so on. These are further divided into acts such as starting a meeting, eliciting opinions, agreeing, disagreeing, starting a presentation, closing a presentation, etc. In an EFL context, these tasks and situations are often limited to formal as opposed to functional aspects of the language given time constraints and limited student access to real languages situations. In this sense, the language is more literal as opposed to metaphorical.

Other researchers have focused specificalIy on four perspectives of ESP: needs, language analysis, materials and methods, and focus. Many of these issues are mentioned throughout this article. Upton (2012: 14) summarizes them as follows (table 1):

\section{TABLE 1}

Upton's (2012: 14) revision of expert scholars' attitudes towards LSP theory

\begin{tabular}{|c|c|c|c|c|}
\hline & $\begin{array}{l}\text { Halliday, Strevens } \\
\text { \& McIntosh } \\
(1964: 189)\end{array}$ & $\begin{array}{c}\text { Strevens } \\
(1977: 150)\end{array}$ & $\begin{array}{l}\text { Dudley Evans } \\
\text { \& St. John } \\
\text { (1998: 4) }\end{array}$ & $\begin{array}{c}\text { Belcher } \\
(2004,2009)\end{array}$ \\
\hline Needs & $\begin{array}{l}\text { Identify the } \\
\text { "specialized" } \\
\text { language used in } \\
\text { specific contexts } \\
\text { that learners need } \\
\text { to know }\end{array}$ & $\begin{array}{c}\text { Focus on "language-using } \\
\text { purposes of the } \\
\text { learner" }\end{array}$ & $\begin{array}{l}\text { "Designed to meet } \\
\text { specific needs of the } \\
\text { learner", including } \\
\text { wants, skill/ } \\
\text { knowledge gaps, etc. }\end{array}$ & $\begin{array}{l}\text { "First and foremost } \\
\text { (before, during, and even } \\
\text { after instruction) finding } \\
\text { out what learner needs } \\
\text { are" (2009: 3) }\end{array}$ \\
\hline $\begin{array}{l}\text { Language } \\
\text { Analysis }\end{array}$ & $\begin{array}{l}\text { "Detailed studies of } \\
\text { restricted languages } \\
\text { and special registers } \\
\text { (...) used by the } \\
\text { particular persons } \\
\text { concerned" }\end{array}$ & $\begin{array}{l}\text { Focus on "communicative } \\
\text { needs" and "language- } \\
\text { using purposes" that are } \\
\text { restricted (by vocabulary, } \\
\text { language skills, themes, } \\
\text { etc.) to those "required by } \\
\text { the learner's purposes" }\end{array}$ & $\begin{array}{l}\text { "Centered on the } \\
\text { language (grammar, } \\
\text { lexis, register), skills, } \\
\text { discourse and } \\
\text { Genres appropriate } \\
\text { to these activities" }\end{array}$ & $\begin{array}{c}\text { Emphasis on "social- } \\
\text { situatedness" of } \\
\text { language use (2004: } \\
\text { 166); understanding of } \\
\text { language use in specific } \\
\text { contexts is essential - } \\
\text { using a variety of analyses }\end{array}$ \\
\hline $\begin{array}{l}\text { Materials \& } \\
\text { Methods }\end{array}$ & $\begin{array}{l}\text { Determine } \\
\text { “appropriate” and } \\
\text { "extra specialized” } \\
\text { teaching materials }\end{array}$ & $\begin{array}{l}\text { Use of methodology } \\
\text { "appropriate to the } \\
\text { learning/teaching } \\
\text { situation" }\end{array}$ & $\begin{array}{l}\text { "Makes use of } \\
\text { the underlying } \\
\text { methodology } \\
\text { and activities of } \\
\text { the disciplines it } \\
\text { serves" }\end{array}$ & $\begin{array}{l}\text { "Developing or adapting } \\
\text { materials and methods } \\
\text { to enable needs- } \\
\text { responsive instruction" } \\
\text { (2009: } 3)\end{array}$ \\
\hline Focus & $\begin{array}{l}\text { Words and } \\
\text { structures }\end{array}$ & Texts and purposes & Learners and genres & $\begin{array}{l}\text { Contexts and } \\
\text { interactions }\end{array}$ \\
\hline
\end{tabular}


Writing and speaking technologies have broadened the field of work to include new approaches to ESP communication (Hamilton \& Woodward-Kron, 2010; Bueno Alastuey, 2011; Hung, 2011; Jackson, 2011; Shih, 2012; Tsai, 2012) and new possibilities for contextualizing teaching (Garcia Laborda, 2009; Ho, 2011; Miller, Hafner \& Fun, 2012) and assessment (Wang \& Chang, 2011; Garcia Laborda, 2013) tasks. In fact, thanks to extensive access to internet on the part of many learners and ESP teachers in EFL contexts, there is a trend towards working with language that is more real; in this sense, the students are starting to focus more on skills as opposed to the formal features of the language.

Despite the emphasis on practical, situation-specific language use in ESP, it should be noted that some groups of learners may be found to have a low overall level of English (Cutting, 2012; Spence \& Liu, 2013). This is often true in EFL settings. In these cases, some of the course content must be General English (Barnard \& Zemach, 2003, in Basturkmen, 2010). Courses of this nature might be found, for example, at universities in non-English speaking countries where the students are recent high-school graduates with relatively low levels of English, a common situation in Spain today. A course syllabus of this type at a Business Faculty might include a combination of language points such as an overview/review of the verb tenses, the comparative and superlative, and the conditional structures alongside such job-specific situations such as participating in meetings, discussing different product options, negotiating or eating with a client at a restaurant. In this situation, tasks tend to be more language centered than when students are more advanced (Iancu, 2000; Denman et al., 2013).

A number of classifications within ESP have been suggested by Carver (1983), Hutchinson \& Waters (1987), and Dudley-Evans \& St. John (1998). Basturkmen (2010) groups ESP courses into three main branches each with their own subdivisions:
1) English for Academic Purposes (EAP), such as English for Academic Publication; 2) English for Professional Purposes (EPP), including medicine, law, the military and so on; and 3) English for Occupational Purposes (EOP), for example, English for technicians. She also groups courses according to when the student initiates ESP learning. Her classification covers three points in a person's professional career: pre-experience, during-experience, and post-experience. As their names imply, pre-experience and during-experience courses are studied prior to or simultaneously with work, but post-experience courses are taken after a person has worked in a field and when he or she is perhaps going through training in an English-speaking country in order to look for work there afterwards.

If our description of the field of ESP has been fairly clear up to this point, it is potentially confusing when we consider it in relation to Content Based Instruction (CBI) and Content Language Integrated Learning (CLIL), as the three approaches show some overlap in that they all permit the integration of content and language. The situation can be understood as a continuum between $\mathrm{CBI}$ and ESP (figure 1 below). The goal of $\mathrm{CBI}$ is to prepare students to acquire language in the context of learning subject matter (for instance, a course on British Cuisine for Vocational Education non-English speaking students in which future cooks learn English indirectly from a class taught in English at the same time), while CLIL concentrates on core contents in a specific subject alongside development of the $L 2$ (for example, a cooking course with the use of modified or simplified English so that the students can learn both the contents and the language). ESP, as mentioned before, focuses on the areas of language required of specific fields so that students can function in specific situations (as in an English course for secretaries in which secretarial skills per se are not taught). Thus, it can be said that the whole needs-based/learner-centered idea pioneered by ESP (Hutchinson \& Waters, 
1987) has tended to diffuse into the different approaches each with a different emphasis mainly whether content or language learning.

One final consideration that must be mentioned before providing our definition of ESP is the distinction between ESP courses in ESL and EFL contexts. While Strevens states that this concern is an "unhelpful polarization" since ESP seems to be a sub-branch of EGP, a few points should be reviewed here. The difference between English for General Purposes and English for Specific Purposes, as seen before, is that the latter is more directed towards the immediate professional or academic demands and applicable situations. For learners in an ESL situation this could mean professional survival in an English-speaking country and not necessarily working at the international level. In this sense, courses are aimed at enriching the worker's competences (Trinder, 2013; Liu, Chang, Yang, \& Sun, 2011; Johns \& Dudley-Evans, 1991). Workers might have limited English skills but they are in an environment where they can find ample opportunities to obtain exposure to the target language. Language practiced in class can be reinforced quickly outside the class. Learners in an EFL setting, on the contrary, often need the language due to the demands of increased globalization and company operation in the international arena. As a result, ESP courses in a foreign-language context must incorporate an international perspective that includes such aspects as cultural concerns and international English language forms and usage. Students having limited language skills in these cases are less able to find chances to practice and reinforce the language learned in the classroom.

Differences in vocabulary and discourse will also shape course design and activities, as well as materials selection. Although in both ESL and EFL settings students acquire content knowledge in addition to language, in the case of ESP in ESL contexts, it will have more direct application than in EFL settings. This is what Carver (1983: 134) refers to as being "concerned with turning learners into [immediate] users". Likewise, while materials for an ESL setting tend to be real and immediately applicable, in an EFL environment they may have a wider range of origins and often be artificially created to accommodate learners' limited access to language use outside the classroom. They are also usually aimed at use in formal instruction.

Taking all of these factors into account, we can now propose a definition of ESP for the EFL context. This field involves the teaching and learning of the foreign language for professional/working purposes in order to facilitate interaction on the part of a working person (whether or not there is remuneration involved) at the international level. Interaction may extend along a continuum from passive interaction, as in the

\section{FIGURE 1}

Continuum according to the learning of contents and foreign language (FL)
Content Based
Content Integrated
Instruction
Language Learning
English for
Specific Purposes

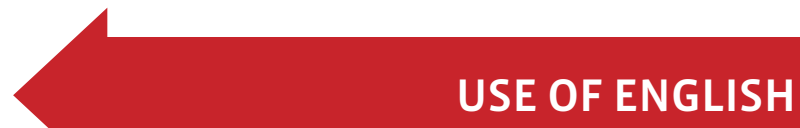
+ contents
- FL learning
- contents
+ FL learning 
case of reading technical materials in the target language, to active interaction, for example, travel to other countries in order to participate in joint projects in the language. For this reason, cultural concerns are a fundamental components of courses alongside general albeit formal language instruction and situational vocabulary, grammar and functional structures.

\section{Current issues}

A number of considerations should be taken into account in designing an ESP course. Hutchinson \& Waters (1987) highlight student needs, learning models and the ways of describing the language as the three most relevant. Dudley-Evans \& St. John (1998) include others such as the discipline, teaching situation, age and socio-cultural status of the students as well as their proficiency level. Fortanet-Gomez \& Raisanen (2008) suggest that nationality may also influence the approaches to ESP based on experience and language proximity. For instance, students in Sweden whose LI is closer to English may need to improve their writing and use a different approach from Spanish learners whose LI is quite different and may need to improve their listening comprehension. Additionally, in some courses there may be regional, national or international interests to develop certain types of programs and courses (Bista, 2011; Basturkmen, 2012; Unterberger, 2012). Another major factor in designing courses is the distinction between the ESL and EFL setting

The objective of a needs analysis is to determine the features of language that students will require in order to progress from an initial stage as learners to specialized learners (Liu et al., 2011; Whittaker et al., 2011) and to design a new curriculum or revise whether changes should be implemented in an existing one (Atai \& Shoja, 2011). For Long (2005), the key issue is not just finding the language that students need but identifying those tasks that they will perform in the L2. For example, some students may have to develop just one linear skill. Cargill, O'Connor \& Li (2012) describe a study in which the only final purpose was to teach Chinese scientists to write for international journals. Another common example in business English could be the design of a syllabus that includes words and expressions from the areas of merchandising and marketing or food and restaurants alongside the functional language for describing an advertising campaign for a new product launch or the language used in ordering food at a restaurant. A definition of needs analysis requires a dynamic methodology based on the use of various methods (a long list of them can be found in Long, 2005: 31-32) and different sources such as teachers, students, linguists, and/or domain experts (Long, 2005). In general, overall competence should be built to produce communicative speech, but professional communication will only be achieved when "prescribed forms" (Master, 1997) are in use and the language reproduces the specific features associated with it in the appropriate context. In this sense, courses should not be so "narrow angled" as to be so restrictive that they can only "help students function in very limited circumstances" (Basturkmen, 2010: 58). Nevertheless, an EFL setting entails certain constraints that make these goals more difficult to achieve. For example, students in the foreign language setting will often have a relatively low level of the target language and limited exposure to it in their everyday lives. This is a handicap in attempting to "produce communicative speech." At the same time, some "prescribed forms" can be targeted but these forms and the overall language taught in the class are often more formal and literal as opposed to metaphorical due to the students' language learning constraints.

Any discussion of needs analyses and authentic or real language must also include discourse communities (McGrath \& Kuteeva, 2012; Flowerdew, 2011) and corpora (Chang, 2011; Walker, 2011; Csomay \& Petrovic, 2012; Nguyen \& Miller, 2012), which have become increasingly important in ESP. The use of large electronic 
databases (concordancers) "allow researchers to conduct systematic searches (...) in spoken and written texts" (Bawarshi \& Reiff, 2010), and they enable identification of the frequencies of occurrence of linguistic features in a particular register so that they can be focused on in language instruction (Bawarshi \& Reiff, 2010). However, since English is a lingua franca spoken by more non-native than native speakers, the issue is raised as to what kind of corpora should be used. In this sense, the VOICE project (Seidlhofer, 2010) of a corpus of spoken language by non-native speakers is worthy of consideration and could be a solution. This is especially the case for EFL situations, as the learners often have more contact with foreign speakers of English than native speakers and often need to communicate with people like themselves, as opposed to learning American or British English. It should be pointed out, however, that while Swales (2009) advocates the extensive use of corpora, he also acknowledges that occasional editing of real complex materials may be required. This is imperative in many EFL situations as the students may have had little to no contact with the language in real situations, for example, in university settings that include an ESP course as part of an undergraduate degree program. These courses take place in the completely artificial language situation: the classroom, so completely authentic materials are often impossible to use.

In establishing a needs analysis and designing courses, the characteristics of ESP students must obviously be born in mind. Learners who are working and studying English at the same time can be expected to have some traits in common according to Harding (2007). For example, they may have been unsuccessful in learning English in the past as they have entered fields not related to language (Kasper, 1997). They may have little time to do any homework as they have jobs outside of class, and in addition, they may be tired or distracted by their work. At the same time, they may not want to be in the sit- uation of having to learn the language but, instead, may be in the class because it is a company requirement. In the EFL setting they are at a special disadvantage as they normally have no outside exposure to the language. In addition, if there is a preference within a company for American or British forms, students may be affected by societal pressures in favor or against the native-speaking culture or they may have a personal bias regarding the variety in question. Finally, the different students in one class may have different levels of proficiency, yet they will have similar jobs. All of these factors will need to be taken into account by the ESP instructor when designing courses and carrying them out on a day-to-day basis.

Apart from these factors, it is worth mentioning that, in most cases, ESP teachers are not experts in the content of what is being taught but instead general language practitioners who may or may not have some background knowledge of the technical area (Sylven, 2013). In this sense, Tudor (1997, in Basturkmen, 2010) indicates that ESP courses often involve content that the average educated native speaker "could not reasonably be expected to be familiar with." While ESP teachers are often university graduates, they may only have a tacit understanding of the features of the language used in the area they are expected to teach. For this reason, they need to "design courses in a conceptual area that one has not mastered and develop the ability to analyse and describe specific texts" (Basturkmen, 2010). Despite the demands of teaching this type of courses, studies by Master (1997) and Howard (1997) (both in Basturkmen, 2010) reveal that few TESOL training programs involved much preparation for teaching ESP at the time they conducted their research. However, the contrary problem has appeared in CLIL courses as the content teachers are bilingual specialists in their fields of study but they cannot help their students to learn the language (Aguilar \& Rodriguez, 2012; Airey, 2012). In some countries in which English 
is being learned as a foreign language through CLIL, such as Spain, there is an effort to team up subject area specialists with native speaker conversation assistants to overcome this difficulty (Méndez \& Pavón, 2012).

When ESP instructors notice a deficit in their language competence, many of them rely on materials as their main sources to link the topics, the language and the method. Textbooks often provide additional materials for both teachers and students such as workbooks with an accompanying $C D$, resource packs with photocopiable activities, grammar booklets, videos, access to a specific website for the book, etc. These materials are of particular importance in the EFL situation as it can help to compensate for the limited outside opportunities for exposure to the target language. When the extra materials include reading and listening practice it is especially beneficial as learners often need to reinforce their ability to use English compared to their capacity to memorize grammar rules and vocabulary lists. At the same time, in recent years the internet has become a source for authentic or nearly authentic materials for almost any subject in ESP (Slaouti, 2002; Rusanganwa, 2013). These, too, serve as opportunities for learners to practice using the language, while providing instructors additional information on the contents of the area in question. Nevertheless, it should be noted that many things available on internet have been produced with specialists in the field in question in mind (Chang \& Kuo, 2011), as opposed to language learners, so the materials may need to be adapted for students through varying degrees of changes in style, register and vocabulary or through the addition of pre-reading and pre-listening activities (García Laborda, 2011; Rusanganwa, 2013), especially in an EFL setting. The different types of materials available on internet to teachers and students of ESP can be of assistance in practicing reading (texts and repositories), listening (podcasts, videos), speaking (through programs such as Skype) and writing (blogs, e-portfolios) (García Laborda, 2011, for a discussion of the variety of materials available online now) (figure 2) or email (Evans, 2012). A new challenge is the use of social networks and mobile-learning materials for ESP, the latter of which can be used by busy students as they commute to and from the workplace.

\section{FIGURE 2}

Current trends in e-materials development for ESP (Garcia Laborda, 2011, with permission)

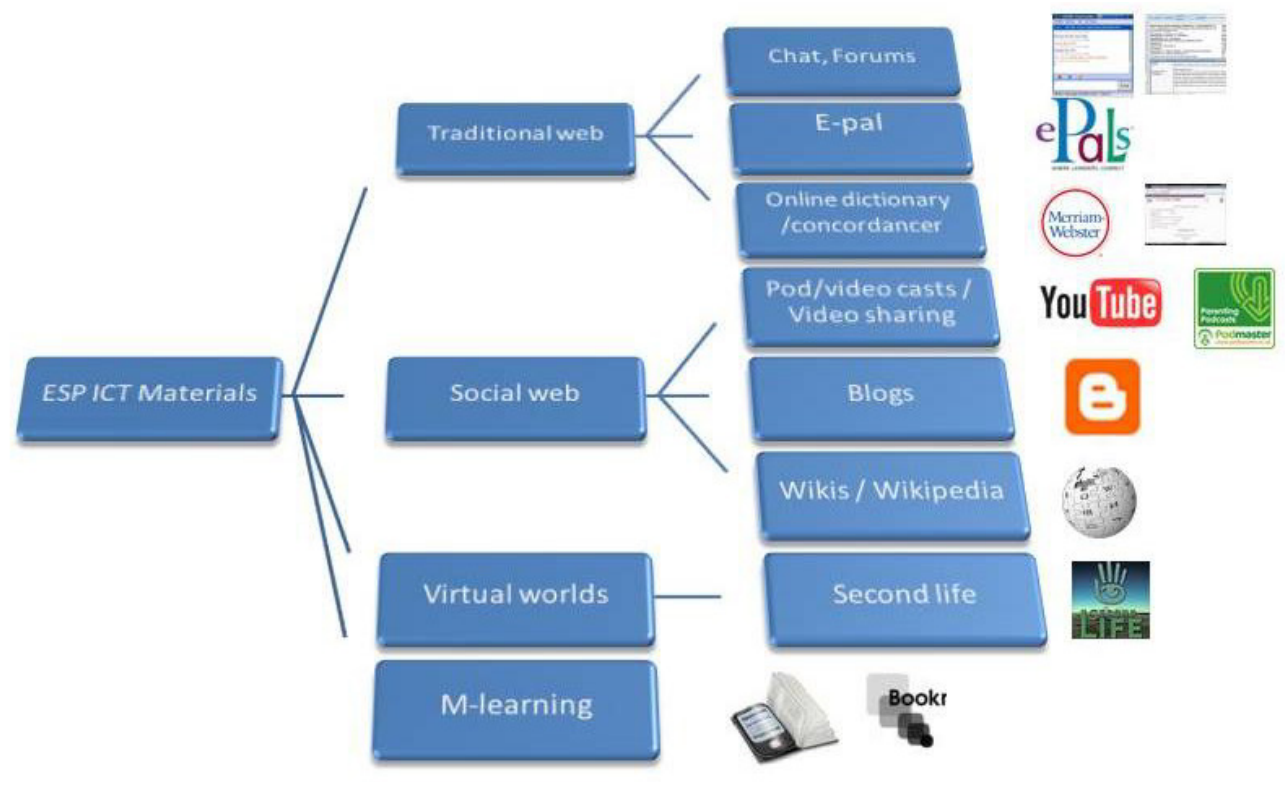




\section{The future}

Research in ESP currently looks at a number of issues including text and discourse analysis, program description, needs analysis (Wozniak, 2010), syllabus design, materials, and methods, but so far little has been published on the topics of teacher training (Gutierrez Almarza, Duran Martinez, \& Beltran Llavador, 2012), testing (Hewings, 2002; Wang \& Chang, 2011), and the effectiveness of ESP courses compared to General English courses (Master, 2005, in Basturkmen, 2010). In the future, ESP will also need to revise the role of technology, the effect of ESP on overall second language acquisition, ESP in new technical, scientific and professional fields (such as English for linguistics), new contexts (i.e. virtual worlds or enhanced reality), new pedagogical ideas such as the application of the theory of the language user (versus language learner) and a serious revision of informal assessment forms. At the same time, the field will also develop thanks to the impact of increased globalization on the study of ESP in the context of EFL, and in particular increased student access to opportunities to practice use of the language in addition to learning formal structures and vocabulary, to compensate for the artificial nature of the classroom. New paradigms of second language acquisition, usually based on the development and definition of socio-cultural competence (Cross, 2012) and the Zone of Proximal Development (Vygotsky, 1978), will also need to be revised in light of ESP; these incude interactional competence, Dynamic Assessment, "extended cognition" and "embodied cognition" and Dynamic Systems. All in all, the future perspectives of practice and research are promising and it will be interesting to see what the next twenty years will bring to this area.

\section{References}

Aguilar, Marta \& Rosa R. Rodriguez, 2012: "Lecturer and student perceptions on CLIL at a Spanish university", International Journal of Bilingual Education and Bilingualism 15(2), 183-197.
AIREY, John, 2012: "'I don't teach language': The linguistic attitudes of physics lecturers in sweden", AILA Review 25, 64-79.

Atal, Mahmood Reza \& Leila ShojA, 2011: "A triangulated study of academic language needs of Iranian students of computer engineering: Are the courses on track?", RELC Journal: A Journal of Language Teaching and Research 42(3), 305323.

Barnard, Roger \& Dorothy Zemach, 2003: "Materials for specific purposes" in B. Tomuinson (ed.): Developing Materials for Language Teaching, London: Continuum, 306-323.

Basturkmen, Helen, 2010: Developing Courses for English for Specific Purposes, New York: Pelgrave-Macmillan.

Basturkmen, Helen, 2012: "Languages for specific purposes curriculum creation and implementation in Australasia and Europe", Modern Language Journal 96, S1, 59-70.

Basturkmen Helen \& Catherine Elder, 2004: "The practice of LSP" in Alan DAvIES \& Catherine ELDER (eds.): The Handbook of Applied Linguistics, Oxford: Blackwell, 672-694.

Bawarshi, Anis S. \& Mary Jo ReifF, 2010: Genre: An Introduction to History, Theory, Research, and Pedagogy, West Lafayette, Indiana: Parlor Press.

Belcher, Diane D., 2004: "Trends in teaching English for specific purposes", Annual Review of Applied Linguistics 24, 165-186.

BelChER, Diane D., 2006: "English for specific purposes: Teaching to perceived needs and imagined futures in worlds of work, study and everyday life", TESOL Quarterly 40(1), 133-156.

Belcher, Diane D., 2009: "How research space is created in a diverse research world", Journal of Second Language Writing 18(4), 221-234.

BISTA, Krishna, 2011: "How to create a learningcentered ESL program”, English for Specific Pur- 
poses World 10(31), 1-13

Bueno Alastuey, Camino M., 2011: "Perceived benefits and drawbacks of synchronous voice-based computer-mediated communication in the foreign language classroom", Computer Assisted Language Learning 24(5), 419-432.

Cargill, Margaret, Patrick O'Connor \& Yongyan LI, 2012: "Educating Chinese scientists to write for international journals: Addressing the divide between science and technology education and English language teaching", English for Specific Purposes 31(1), 60-69.

Carver, David, 1983: "Some propositions about ESP”, The ESP Journal 2, 131-137.

Chang, Ching-Fen \& Chih-Hua Kuo, 2011: "A corpusbased approach to online materials development for writing research articles", English for Specific Purposes 30(3), 222-234.

Cross, Russell, 2012: "Creative in finding creativity in the curriculum: The CLIL second language classroom", Australian Educational Researcher 39(4), 431-445.

Csomay, Eniko \& Marija Petrovic, 2012: “'Yes, your honor!': A corpus-based study of technical vocabulary in discipline-related movies and TV shows", System: An International Journal of Educational Technology and Applied Linguistics 40(2), 305-315

Cutting, Joan, 2012: "English for airport ground staff”, English for Specific Purposes 31(1), 3-13.

Denman, Jenny, Rosie Tanner \& Rick de Graaff, 2013: "CLIL in junior vocational secondary education: Challenges and opportunities for teaching and learning", International Journal of Bilingual Education and Bilingualism 16(3), 285-300.

Dudley-Evans, Tony \& Maggie Jo ST. John, 1998: Developments in English for Specific Purposes: A Multi-Disciplinary Approach, Cambridge, Cambridge University Press.
Evans, Stephen, 2012: "Designing email tasks for the business English classroom: Implications from a study of Hong Kong's key industries", English for Specific Purposes 31(3), 202-212.

Flowerdew, John, 2011: "Action, content and identity in applied genre analysis for ESP", Language Teaching 44(4), 516-528.

Fortanet-Gómez, Inmaculada \& Christine A. RäisÄnen (eds.), 2008: ESP in European Higher Education: Integrating Language and Content, Amsterdam: John Benjamins.

Friginal, Eric, 2013: "Evaluation of oral performance in outsourced call centres: An exploratory case study", English for Specific Purposes 32(1), 25-35.

García Laborda, Jesús, 2009: "Using Webquests for Oral Communication in English as a Foreign Language for Tourism Studies", Educational Technology \& Society 12(1), 258-270.

García LabORDA, Jesús, 2011: "Revisiting materials for teaching Languages for Specific Purposes", $3 L$ The Southeast Asian Journal of English Language Studies 17(1), 102-112.

García LaboRdA, Jesús, 2013: "Alternative assessment in English for Tourism through Web 2.0" in G. Bosch \& T. Schlak (eds.): Teaching Foreign Languages for Tourism, New York: Peter Lang, 89106.

Greer, Rachelle R., 2012: "Introducing plain language principles to business communication students", Business Communication Quarterly 75(2), 136-152.

Gutierrez Almarza, Gloria, Ramiro Duran Martinez \& Fernando Beltran Llavador, 2012: "CLIL in teacher training: A Nottingham Trent university and University of Salamanca experience", Encuentro 21, 48-62.

Halliday, Michael Alexander Kirkwood, Angus McLntosh \& Peter Strevens, 1964: The Linguistic Scien- 
ces and Language. Teaching, London: Longmans. Hamilton, Jan \& Robyn Woodward-Kron, 2010: "Developing cultural awareness and intercultural communication through multimedia: A case study from medicine and the health sciences", System: An International Journal of Educational Technology and Applied Linguistics 38(4), 560-568.

HARDING, Keith, 2007: English for Specific Purposes, Oxford: Oxford University Press.

HewINGs, Martin, 2002: "A history of ESP through English for Specific Purposes", ESP World 3 [http:// www.esp-world.info/Articles_3/Hewings_paper. htm, fecha de consulta: 12.06.2011].

Ho, Belinda, 2011: "Solving the problems of designing and teaching a packed English for specific purposes course", New Horizons in Education 59(1), 119-136.

Howard, Ron, 1997: “'LSP in the UK'” in Ron Howard \& Gillian Brown (eds.): Teacher Education for LSP, Clevedon: Multilingual Matters, 41-57.

Howatt, Anthony P. R. \& Henry G. Widdowson (intro), 2004 [1984]: A History of English Language Teaching, second edition, Oxford, UK: Oxford University Press.

Hung, Shao-Ting, 2011: "Pedagogical applications of blogs: An investigation into ESP learners' perceptions", British Journal of Educational Technology 42(5), 736-746.

Hutchinson, T. \& A. Waters, 1987: English for Specific Purposes, Cambridge: Cambridge University Press.

Iancu, M. A., 2000: "Implementing fluency first activities in an intermediate-level EAP reading class", TESOL Journal 9(2), 11-16.

Ioannou Georgiou, S., 2012: "Reviewing the puzzle of CLIL”, ELT Journal 66(4), 495-504.

JaCkson, Daniel O., 2011: "Convergent and diver- gent computer-mediated communication tasks in an English for academic purposes course", TESL-EJ 15(3), 18-18.

Johns, Anne M. \& Tony Dudley-Evans, 1991: "English for specific purposes: International in scope, specific in purpose", Teaching English to Speakers of Other Languages Quarterly 25(2), 297-314.

KASPER, Loretta Frances, 1997: "The impact of content-based instructional programs on the academic progress of ESL students", English for Specific Purposes 16(4), 309-320.

Liu, Jin-Yu, Yu-Hung Chang, Fang-Ying Yang \& YuChih Sun, 2011: "Is what I need what I want? Reconceptualising college students' needs in English courses for general and Specific/Academic purposes", Journal of English for Academic Purposes 10(4), 271-280.

LoNG, Michael H., 2005: "Methodological issues in learner needs analysis" in Michael H. Long (ed.): Second Language Needs Analysis, Cambridge: Cambridge University Press, 19-76.

MASTER, Peter, 1997: “Using models in EST”, English Teaching Forum 35(4), 30-37.

Master, Peter, 2005: "English for specific purposes" in E. Hinkel (ed.): Handbook of Research in Second Language Teaching and Learning, Mahwah, NJ: Lawrence Erlbaum Associates, 99-115.

McDonough, Jo, 1999: "English for specific purposes (ESP)" in Keith Johnson \& Helen Johnson: Encyclopedic Dictionary of Applied Linguistics: A Handbook for Language Teaching, Oxford: Blackwell Publishing Ltd, 105-120.

McGrath, Lisa \& Maria Kuteeva, 2012: "Stance and engagement in pure mathematics research articles: Linking discourse features to disciplinary practices", English for Specific Purposes 31(3), 161-173.

Méndez, María Carmen \& Victor Pavón, 2012. "Investigating the coexistence of the mother ton- 
gue and the foreign language through teacher collaboration in CLIL contexts: perceptions and practice of the teachers involved in the plurilingual programme in Andalusia", International Journal of Bilingual Education and Bilingualism 15(5), 573-592.

Miller, Lindsay, Christoph A. Hafner, \& Connie NG KWAl Fun, 2012: "Project-based learning in a technologically enhanced learning environment for second language learners: Students' perceptions", E-Learning and Digital Media 9(2), 183-195.

Mohan, Bernard A., 1986: Language and Content, Reading, MA: Addison-Wesley.

Nguyen, Hai \& Jennifer Miller, 2012: "Exploring business request genres: Students" rhetorical choices", Business Communication Quarterly 75(1), 5-28

Nordmeyer, Jon \& Susan BaRduHn, 2010, : Integrating Language and Content, Alexandria, Virginia: TESOL Publications.

Richards, Jack C. \& Richard W. SCHmidT, 2010: Longman Dictionary of Language Teaching and Applied Linguistics, fourth edition, London: Longman (Pearson Education).

Rusanganwa, Joseph, 2013: "Multimedia as a means to enhance teaching technical vocabulary to physics undergraduates in Rwanda", English for Specific Purposes 32(1), 36-44.

Seidlhofer, Barbara, 2010: "Giving VOICE to English as a lingua franca” in R. Facchinetti, D. Crystal \& B. Seidlhofer (eds.): From International to Local English and Back Again, Frankfurt: Peter Lang, 147-163.

SHIH, Ru-Chu, 2012: "Integrating blog and face-toface instruction into an ESP course: English for hospitality and tourism", Turkish Online Journal of Educational Technology-TOJET 11(4), 204-209.

Slaouti, Diane, 2002: "The World Wide Web for academic purposes: old study skills for new?",
English for Specific Purposes 21(2), 105-124.

Spence, Paul \& Gi-Zen LIU, 2013: "Engineering English and the high-tech industry: A case study of an English needs analysis of process integration engineers at a semiconductor manufacturing company in Taiwan", English for Specific Purposes 32(2), 97-109.

Strevens, Peter, 1977: New orientations in the teaching of English, Oxford: Oxford University Press.

SWALES, John M., 2009: "When there is no perfect text: Approaches to the EAP practitioner's dilemma", Journal of English for Academic Purposes 8, 5-13.

Sylven, Liss Kerstin, 2013: "CLIL in sweden why does it not work? A metaperspective on CLIL across contexts in Europe", International Journal of Bilingual Education and Bilingualism 16(3), 301-320.

TrInDER, Ruth, 2013: "Business students' beliefs about language learning in a university context”, English for Specific Purposes 32(1), 1-11.

Trinder, Ruth \& Martin Herles, 2013: "Students' and teachers' ideals of effective business English teaching", ELT Journal 67(2), 220-229.

Tsal, Shu-Chiao, 2010: "Developing and integrating courseware for oral presentations into ESP learning contexts", Computers \& Education 55(3), 1245-1258

TSAl, Shu-Chiao, 2012: "Integration of multimedia courseware into ESP instruction for technological purposes in higher technical education", Educational Technology \& Society 15(2), 50-61.

TUdor, Ian, 1997: "LSP or Language Education?” in Ron Howard \& Gillian Brown (eds.): Teacher Education for LSP, Clevedon: Multilingual Matters, 90102.

UnteRBERGER, Barbara, 2012: "English-medium programmes at Austrian business faculties: A status quo survey on national trends and a case study on programme design and delivery", AILA Review 
25, 80-100.

Upton, Thomas A., 2012: "LSP at 50: Looking back, looking Forward”, Ibérica 23, 9-28.

VyGotsky, Lev Semiónovich, 1978: Mind in Society, Cambridge, MA: Harvard University Press.

WalkeR, Crayton, 2011: "How a corpus-based study of the factors which influence collocation can help in the teaching of business English", English for Specific Purposes 30(2), 101-112.

WANG, Li-Jyu \& Hung-Fan ChANG, 2011: "Improve oral training: The method of innovation assessment on English speaking performance", International Journal of Distance Education Technologies 9(3), 56-72.

Whittaker, Rachel, Ana Llinares \& Anne McCabe, 2011: "Written discourse development in CLIL at secondary school", Language Teaching Research 15(3), 343-362.

WozNIAK, Séverine, 2010: "Language needs analysis from a perspective of international professional mobility: The case of French mountain guides", English for Specific Purposes 29(4), 243-252. 